\title{
ENERGY CONSUMPTION, TRADE OPENNESS AND ECONOMIC DEVELOPMENT OF SOME MAJOR OIL-PRODUCING COUNTRIES IN AFRICA
}

\section{Samuel Orekoya ${ }^{1}$ and Peter Oluleke ${ }^{2}$}

\author{
${ }^{1}$ Department of Economics, University of Ibadan, Nigeria.
}

${ }^{2}$ Centre for Petroleum, Energy Economics and Law (CPEEL), University of Ibadan, Nigeria.

Cite this article:

Samuel O., Peter O. (2021), Energy Consumption, Trade Openness and Economic Development of Some Major Oil-Producing Countries in Africa. African Journal of Economics and Sustainable Development 4(1), 45-62. DOI: 10.52589/AJESD41C2IGQJ.

\section{Manuscript History}

Received: 10 March 2021

Accepted: 6 April 2021

Published: 14 May 2021

Copyright $\odot 2020$ The Author(s). This is an Open Access article distributed under the terms of Creative Commons AttributionNonCommercial-NoDerivatives 4.0 International (CC BY-NC-ND 4.0), which permits anyone to share, use, reproduce and redistribute in any medium, provided the original author and source are credited.

\begin{abstract}
S: To investigate the nexus between energy consumption, trade openness and economic development for seven oil-producing countries in Africa, this study employs the panel Autoregressive Distributive Lag (ARDL) techniques on data from 1971 to 2017. The Levin-Lin-Chiu, Pesaran-Shin and Breitung tests were used to ascertain the stationarity of the variables. The Hausman test showed that the mean group heterogeneous ARDL is the best technique to estimate the short and long-run relationship of the model. The result revealed that trade openness and the nature of energy consumed have significant impacts on economic development in the selected oilproducing countries. A percentage increase in trade openness decreases economic development by about seven percent in the short run but boosts development by twenty-eight percent in the long run. From the findings, it is recommended that policies be channelled to favour enabling environment, African free trade zone, economic freedom, private financial growth, ease of doing business, energy efficiency, renewable energy, carbon capture and storage, private property rights and security in Africa.
\end{abstract}

KEYWORDS: Trade Openness, Economic Development, Energy Consumption, CO2 Emission.

JEL Classifications: F40, F18, P43 


\section{INTRODUCTION}

Trade openness refers to the outward or inward movement of goods and services from a sovereign nation and this has been measured in various ways by studies investigating the issue. The most basic measure of openness is trade shares (outcome openness measure), which is exports plus imports divided by GDP, used by a large number of studies that finds a positive and strong relationship with growth. The other is the measure of trade barriers (policy openness measures) such as average tariff rates, export taxes, taxes on international trade and indices of non-tariff barriers (NTBs) which measure the trade restrictiveness of countries. Tariffs, defined as the ratio of tariff revenues to import values, directly measure trade restrictions but their impact on growth remains controversial.

Despite the numerous benefits associated with free trade, African countries have not embraced trade liberalization in the manner that other developing regions have. Protectionists' measures have taken various forms including tariffs, quantitative restrictions, exchange controls and downright import bans. Zahonogo (2017) reveals that a significant number of researchers have attributed the poor performance of African economies to the protectionist trade practices. However, it has been stressed that; while opening an economy to trade may not provide the desired quick fix, the removal or reduction of quantitative import and export restrictions and lowering of tariffs would result in increased and sustainable development.

To create a single market for goods, services and facilitate movement of persons to deepen the economic integration of the African continent and in accordance with the Pan African vision of "an integrated, prosperous and peaceful Africa" enshrined in Agenda 2063, The African Continental Free Trade Area (AfCFTA) was brokered by the African Union (AU) and signed by 44 of its 55 member states in Kigali, Rwanda on March 21, 2018. Subsequently, 10 other countries joined including Nigeria to sign the law on the 7th of July, 2019. The agreement requires members to remove tariffs from $90 \%$ of goods and allow free access to goods and services across the continent. By implication, the United Nations Economic Commission for Africa (UNECA) estimates that the agreement will boost intra-African trade by 52 percent by 2022 in its energy exchange.

Energy consumption comes from the different energy mix. It includes fossil fuels (oil, natural gas and coal), nuclear energy, non-renewable waste and the many sources of renewable energy (wood, biofuel, the hydro, wind, solar, geothermal, heat from heat pumps, renewable waste and biogas). These primary energy sources are used for generating power, providing fuel for transportation, heating and cooling residential and industrial buildings. Energy is at the heart of many of the Sustainable Development Goals (SDG) - from expanding access to electricity to improving clean cooking fuels, from reducing wasteful energy subsidies to curbing deadly air pollution that each year prematurely kills millions around the world. One of these goals commonly known as SDG 7 - aims at ensuring access to affordable, reliable, sustainable and modern energy for all by the end of the next decade.

Access to energy is crucial not only for the attainment of health and education outcomes but also for reducing the cost of doing business and for unlocking economic potential and creating jobs. However, Africa is one of the worst-performing regions in terms of access to better energy as the use of wood-burning cooking stoves and other unclean sources of energy coupled with insufficient energy access have resulted in hundreds of thousands of deaths annually (IEA, 2017a). These, by effect, has undermined the operations of hospitals and emergency services; 
African Journal of Economics and Sustainable Development

ISSN: 2689-5080

Volume 4, Issue 1, 2021 (pp. 45-62)

www.abjournals.org

compromised educational attainment; and drove up the cost of doing business. Energy access for all is, therefore, one of the key drivers of inclusive growth as it creates opportunities for women, youths, children both in the urban and rural areas. Africa's energy potential, especially renewable energy, is enormous, yet only a fraction of it is currently being explored. Hydropower provides around a fifth of current capacity but not even a tenth of its total potential is being utilized (AfDB, 2017).

Literature is replete with factors driving economic development. However, empirical studies remain gaunt and inconclusive on the role of trade and energy consumed in achieving economic development, especially in Africa. Thus, this study becomes imperative in investigating the relationship between energy consumption, trade openness and economic development for some selected oil-producing countries in Africa viz: Nigeria, Algeria, Congo, Egypt, Gabon, Sudan and Tunisia. Specifically, the study aims to empirically: assess the impact of energy consumption on GDP per capita of some selected oil-producing countries in Africa, examine the effect of trade openness on GDP per capita of these selected countries and ascertain the causality between energy consumption, trade openness and economic development.

\section{Trend Analysis of Macroeconomic Variables}

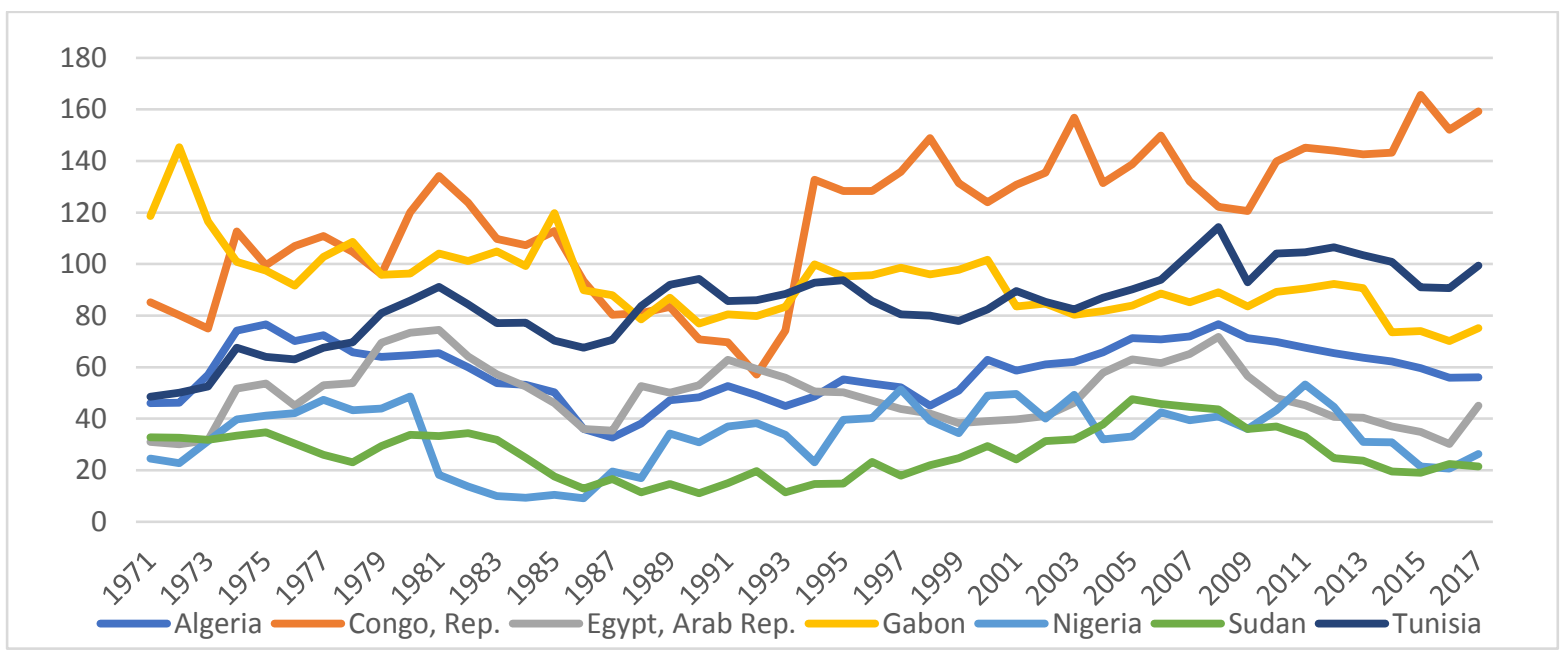

Figure 1: Trade openness of selected oil-producing countries in Africa

Source: Author's Computation

Trade for the Congo Republic was observed to be above the other selected countries in virtually all the years under review. This volatility of trade can be attributed to the inconsistent policy of the head of state under President Mobutu. The trade of Sudan was seen to be at the bottom of all other countries under investigation. This should not come as a surprise as the country is ravaged by internal civil war for a very long time. However, all other countries under study show a great level of instability in the trends over time. 
African Journal of Economics and Sustainable Development

ISSN: $2689-5080$

Volume 4, Issue 1, 2021 (pp. 45-62)

www.abjournals.org

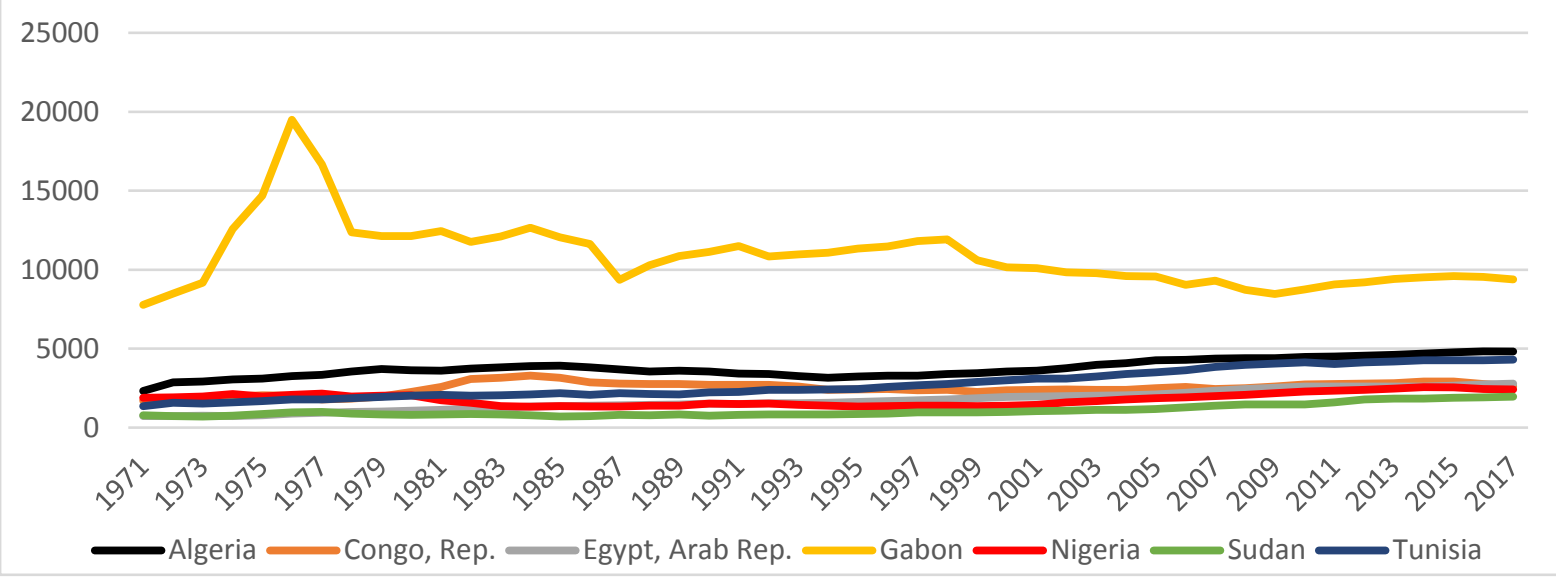

Figure 2: GDP per capita of selected oil Producing Countries in Africa

Source: Author's Computation

Of the countries selected, Gabon stood tall in terms of GDP per capita with a record high of about $\$ 20,000$ and the least value of about $\$ 7,500$. The feat was due to the country's low population (about 2 million as of 2016) since the 1960s. Also, the monetary value of goods and services produced in Gabon over the years was very significant compared to others. All other counties, in which Nigeria is prominently revered, were noted to be within the threshold of $\$ 5,000$. Without a doubt, Nigeria has the highest GDP among these countries but this is accompanied by a high population which puts Nigeria in the same rank as the other countries.

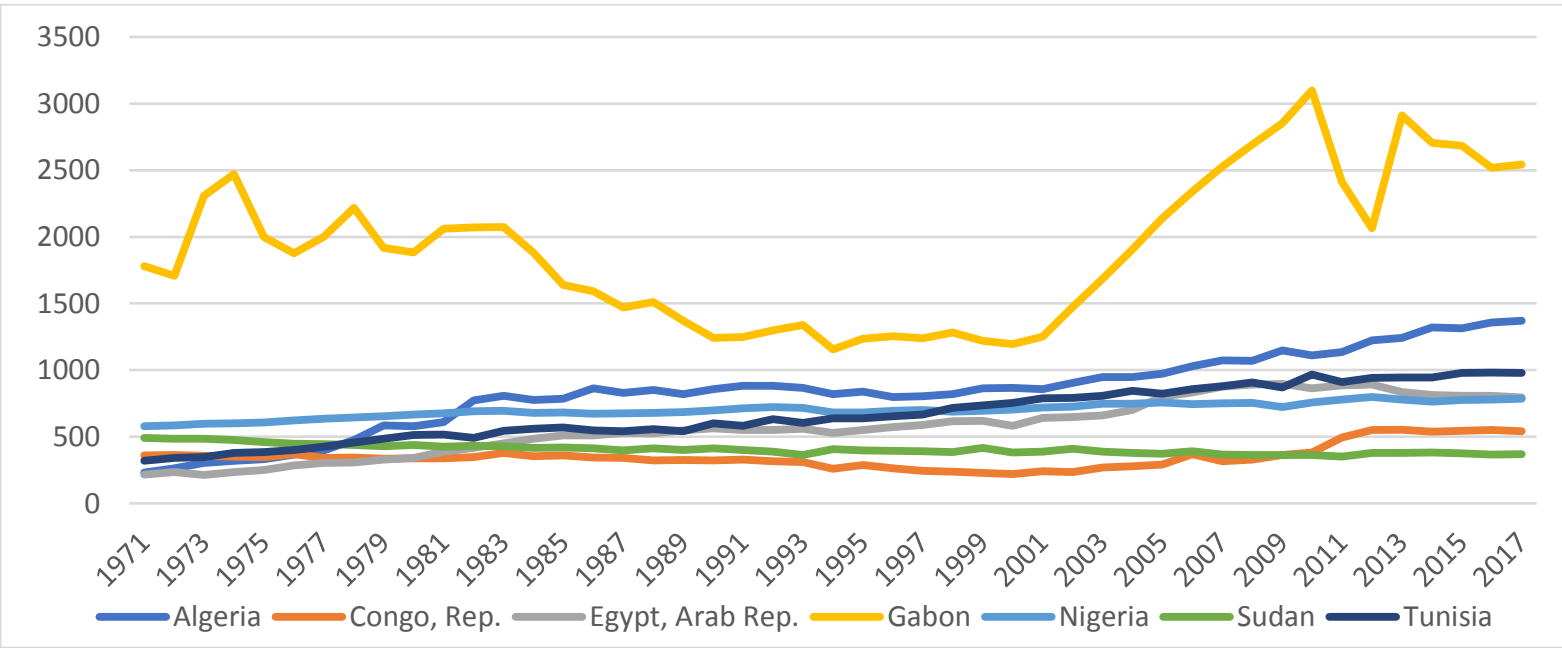

Figure 3: Energy consumption of selected oil-producing countries in Africa

Source: Author's Computation 
The energy use, expressed as the Kg of oil equivalent per capita of the countries shows Gabon atop of other countries with a record high of about 3,000 and the least value of about 1,100. This position was due to its very low population (about 2million as of 2016) since the 1960s. All the other countries operated in the threshold of 1,000 except Algeria which had improvement from the year 2007 upward. The $\mathrm{Kg}$ of oil equivalent per capita as a proxy for oil energy used for Nigeria was relatively stable due to the sizeable number of Nigerians still using the traditional source of energy such as charcoal, firewood and others for cooking. The relative increase in energy use can be attributed to the Nigerian government implementation of a new minimum wage.

\section{Oil Production of Selected Oil Producing Countries in Africa}

Table 1. Oil: Production in Million Tons- BI Statistics

\begin{tabular}{|c|c|c|c|c|c|c|c|c|}
\hline \multicolumn{6}{|c|}{ Oil: Production in Million Tons- BI Statistics } & \multicolumn{2}{c|}{$\begin{array}{c}\text { Growth rate per } \\
\text { annum }\end{array}$} & $\begin{array}{l}\text { Share of } \\
\text { Total }\end{array}$ \\
\hline Country & $\mathbf{2 0 1 3}$ & $\mathbf{2 0 1 4}$ & $\mathbf{2 0 1 5}$ & $\begin{array}{c}\mathbf{2 0 1} \\
\mathbf{6}\end{array}$ & $\begin{array}{c}\mathbf{2 0 1} \\
\mathbf{7}\end{array}$ & $\mathbf{2 0 1 7}$ & $\mathbf{2 0 0 6 - 1 6}$ & $\mathbf{2 0 1 7}$ \\
\hline Nigeria & 109.5 & 109.4 & 105.8 & 91.4 & 95.3 & $4.50 \%$ & $-2.30 \%$ & $2.20 \%$ \\
\hline Algeria & 64.8 & 68.8 & 67.2 & 68.4 & 66.6 & $-2.30 \%$ & $-2.30 \%$ & $1.50 \%$ \\
\hline Egypt & 34.4 & 35.1 & 35.4 & 33.8 & 32.2 & $-4.60 \%$ & $0.20 \%$ & $0.70 \%$ \\
\hline Congo & 12.6 & 13.3 & 12.4 & 12.6 & 14.7 & $17.00 \%$ & $-1.20 \%$ & $0.30 \%$ \\
\hline Gabon & 11.3 & 11.3 & 11.2 & 11 & 10 & $-9.30 \%$ & $-0.90 \%$ & $0.20 \%$ \\
\hline Sudan & 5.8 & 5.9 & 5.4 & 5.1 & 4.2 & $-17.00 \%$ & $-11.60 \%$ & $0.10 \%$ \\
\hline Tunisia & 3.5 & 3.3 & 2.9 & 2.8 & 2.4 & $-12.10 \%$ & $-2.40 \%$ & $0.10 \%$ \\
\hline
\end{tabular}

Source: Author's Computation

Nigeria maintains the lead in oil production among the selected oil-producing countries in Africa. In 2013, Nigeria, Algeria, Egypt, Congo and Gabon produced 109.5, 64.8, 34.4, 12.6 and 11.3 million tons of oil respectively. Nigeria produced more than double of any of the selected country except Algeria. This feat was made possible for Nigeria because of the level of oil deposit in the country, the cumulative effect of investment in the oil and gas industry over the years as well as the government's policy that stylishly supported the mono-economy. Oil production in Nigeria declined marginally from 109.5 to 109.4 and 105.8 million tons respectively in the years 2013, 2014 and 2015. This might not be unconnected with the international politics in the global oil market where the Organization of Petroleum Exporting Countries (OPEC) regulates the volume of oil production to its members. However, in 2016 and 2017, oil production was seen to have declined due to a long and persistent decrease in oil price in the international market as well as the activities of the Niger-Delta militant group(s) in the oil-producing area of Nigeria.

Algeria occupies the second position after Nigeria going by the millions of tons being produced over the years. The trend in oil production was smooth with little deviation from the mean production over the years. It may not be unconnected to the domestic policy put in place by the successive government of the country and the absence of militant activity to disrupt oil 
African Journal of Economics and Sustainable Development

ISSN: 2689-5080

Volume 4, Issue 1, 2021 (pp. 45-62)

www.abjournals.org

production and exportation. The marginal deviation from oil production can be traced to OPEC regulation.

Among the selected oil-producing countries in Africa, Egypt occupies the third position in respect of millions of tons of oil produced and the consistency in the production. This may be due to the fact that the economy of Egypt is not driven by one but many sectors such as manufacturing, agriculture among others. Congo and Gabon were relatively close to each other in millions of tons of oil production.

\section{Economic Freedom of Selected Oil Producing Countries in Africa}

Table 2. Economic Freedom in Africa

\begin{tabular}{|c|c|c|c|c|c|c|c|}
\hline Country & Tunisia & Egypt & Nigeria & Algeria & Gabon & Sudan & Congo \\
\hline World Rank & 125 & 144 & 111 & 171 & 118 & 166 & 176 \\
\hline Region Rank & 10 & 11 & 14 & 14 & 17 & 41 & 46 \\
\hline 2019 Score & 55.4 & 52.5 & 57.3 & 46.2 & 56.3 & 47.7 & 39.7 \\
\hline Tax Burden & 74.4 & 85.2 & 85 & 76.4 & 75.8 & 86.3 & 59.5 \\
\hline Business Freedom & 76.7 & 65.9 & 51.2 & 61.6 & 52.1 & 52.1 & 38.2 \\
\hline Trade Freedom & 71.4 & 71.8 & 62.4 & 67.4 & 51.2 & 45 & 56.8 \\
\hline Tariff Rate (\%) & 9.3 & 6.6 & 11.3 & 8.8 & 16.9 & 17.5 & 11.6 \\
\hline Income Tax Rate (\%) & 35 & 25 & 24 & 35 & 35 & 10 & 45 \\
\hline $\begin{array}{c}\text { Corporate Tax Rate } \\
(\%)\end{array}$ & 30 & 23 & 30 & 23 & 30 & 35 & 34 \\
\hline GDP per capita (PPP) & $\$ 11,755$ & $\$ 12,671$ & $\$ 5,929$ & $\$ 15,237$ & $\$ 19,254$ & $\$ 4,586$ & $\$ 6,642$ \\
\hline
\end{tabular}

Source: Author's Computation.

Of the selected African countries, according to the World rank of the economic freedom index, Nigeria ranked better among the selected countries. However, the country ranked 111 and 14 positions in the world rank and regional rank respectively. In other words, the Nigerian economy is fairly open to other countries with the least bottleneck for business. This position should not be surprising as the country has been putting necessary machinery in place to attract foreign direct investment into the country. On the other hand, Sudan's world rank of 166 and regional rank of 41 can be attributed to the political unrest that has scared away existing and potential investors from the country.

\section{Ease of Doing Business in Selected Oil Producing Countries in Africa}

Table 3: Ease of Doing Business in Africa

\begin{tabular}{|l|c|c|c|c|c|c|c|}
\hline Economy & Tunisia & Egypt & Nigeria & Algeria & Sudan & Gabon & $\begin{array}{l}\text { Congo, } \\
\text { Rep. }\end{array}$ \\
\hline Global Ranking & 80 & 120 & 146 & 157 & 162 & 169 & 180 \\
\hline Starting a Business & 63 & 109 & 120 & 150 & 156 & 124 & 179 \\
\hline Dealing with & & & & & & & \\
Construction Permits & 77 & 68 & 149 & 129 & 105 & 144 & 127 \\
\hline Getting Electricity & 51 & 96 & 171 & 106 & 120 & 161 & 182 \\
\hline
\end{tabular}


African Journal of Economics and Sustainable Development

ISSN: $2689-5080$

Volume 4, Issue 1, 2021 (pp. 45-62)

www.abjournals.org

\begin{tabular}{|l|c|c|c|c|c|c|c|} 
Registering Property & 87 & 125 & 184 & 165 & 93 & 178 & 177 \\
\hline Getting Credit & 99 & 60 & 12 & 178 & 161 & 124 & 134 \\
\hline $\begin{array}{l}\text { Protecting Minority } \\
\text { Investors }\end{array}$ & 83 & 72 & 38 & 168 & 168 & 161 & 149 \\
\hline Paying Taxes & 133 & 159 & 157 & 156 & 163 & 183 & 185 \\
\hline Trading across Borders & 101 & 171 & 182 & 173 & 185 & 170 & 184 \\
\hline Enforcing Contracts & 80 & 160 & 92 & 112 & 144 & 180 & 155 \\
\hline Resolving Insolvency & 67 & 101 & 149 & 76 & 118 & 129 & 122 \\
\hline
\end{tabular}

Source: Author's Computation

In the global ranking, Tunisia ranked $80^{\text {th }}$ position while Egypt and Nigeria were respectively in number 120th and 146th. In the ranking, starting a business, dealing with construction permits, getting electricity, registering property, getting credit, minority investment protection, paying taxes, trading across borders, enforcing contracts and resolving insolvency were all considered. Nigeria for example ranks 12 in areas of getting credit facilities from financial institutions. The lower this value, the better the ease of doing business. Sudan and the Congo Republic ranked worst in all standards of selected countries. This may be connected to the prolonged military leadership in the countries and their ambition to rule for life. Availability of electricity happens to be one of the social infrastructures that attract and simplifies ways of transacting business. Most of the African countries cannot guaranty an 18-hour electricity supply per day and this is part of the reasons the rankings of the countries were far from the first 20 in the global ranking.

\section{The African Continental Free Trade Area (AfCFTA)}

As of July 2019, the AfCFTA agreement was signed by 54 of the 55 African Union nations, with Eritrea being the only nation yet to sign. Ghana, Kenya, Rwanda, Niger, Chad, Congo, Djibouti, Guinea, Eswatini, Mali, Mauritania, Namibia, South Africa, Uganda, Ivory Coast (Côte d'Ivoire), Senegal, Togo, Egypt, Ethiopia, Gambia, Sierra Leone, Saharawi Republic, Zimbabwe, Burkina Faso, Sao Tome and Príncipe, Gabon, and Ethiopia are the 27 nations that have further deposited their AfCFTA instruments with the Chairperson of the African Union Commission (AUC).

\section{LITERATURE REVIEW}

Researches conducted to establish the linkages between energy consumption, trade openness and economic development by authors from the developed and developing countries have come up with various findings. Odularu (2008) analyzed the relationship between the oil sector and Nigeria economic performance using the OLS estimation technique. The study empirically established that crude oil production has contributed in no small measure to the economic growth of Nigeria. Findings further showed that any of the variables used as the dependent variable, be it labour, capital or crude oil export will bring about an increase in the real GDP.

Zeren and Ari (2013) investigated trade openness and economic growth for the G7 countries (Germany, France, Italy, UK, USA, Japan and Canada) with data from 1970 to 2011 using panel causality test (a simple version of the Granger non-causality test) for the nonhomogenous panel model of data with fixed coefficients. The study found a bi-directional 
causal relationship between trade openness and economic growth. This empirical evidence gives kudos to the hypothesis that openness increases economic growth as opined by the endogenous theory of growth. A similar empirical study by Jung and Marshall (1985) for Southeast Asia with data from 1950 to 1981 provided evidence that the OLS analysis obtained were not the same for the countries analyzed. For instance, exports caused growth in Indonesia while the reverse is the case in Thailand. However, no causal relationship was established between Taiwan and the Philippines while two other counties showed no causal relationship.

To advance the frontiers of knowledge, Ackah (2013) employed an unconditional general equilibrium trade model on the trade dataset from 1980 to 2003 to investigate the impact of trade costs on the Economic Community of West African States (ECOWAS) trade flows. Findings from the study show that the cost of intra-regional trade in the ECOWAS region is lower compared to what obtains in the sub-Saharan Africa (SSA) region or other regional groups. The researchers however opined that this condition is due to the positive impact of integration efforts on regional trade and promotion of robust policies on intra-ECOWAS trade.

Vehepi (2014) empirically analyzed the effects of trade openness on the economic growth of ten South-East European countries using GMM and OLS techniques on data from 1996 to 2005. The study empirically established that the initial GDP per capita variable coefficients in all the models are positively and statistically significant at 1percent as against the negative sign expected according to the Solow growth model. From the pooled OLS, the coefficient is found to be greater than one compared to other regression results whose coefficient of this variable is less than one. This implies that poorer South-East European countries tend to develop and grow faster than the rich ones. However, it should be noted that these fast-growing countries may converge to different levels of per capita GDP since the model provides for structural differences among countries via a set of explanatory variables. Also, the trade openness coefficient was found to be positively and statistically significant at 5percent level in the fixed effects model as well as in the difference and system GMM models but fails to show robust evidence in pooled OLS, hence the positive sign relationship is not significant. Better still, the correlation coefficient between the GDP per capita logarithm and trade openness logarithm with pooled OLS estimation is negative and insignificant which evidenced that trade openness does not exert a significant effect on the growth of the South-East European countries.

In researching the connection between trade openness, banking sector and economic growth in 25 countries of the ASEAN region between 1961 to 2012, Pradhan (2017) used panel data estimation techniques. To capture the depth of the banking sector, five measures were taken which are broad money supply to national income, private sector claims to national income, private domestic credit to national income, domestic credit given by a bank to national income, and the depth index of the banking sector. Three dynamic panel regressions were estimated to examine the long-run causal relationship between per capita economic growth, banking depth and trade openness in the economy. The lagged error term was statistically significant at a one percent level which implies that GDP tends to converge at the long-run equilibrium path to respond to regressors' changes. The significance of the coefficient lagged error correction term in the GDP equation in the five models each affirms the existence of a long-run equilibrium between GDP and its stated determinants. In other words, it is empirically shown that trade openness and banking sector depth Granger-cause economic growth in the long run.

Zahonogo (2017) examined trade and the economic growth of 42 developing countries in SubSaharan Africa (SSA) using pooled mean group estimation technique on data from 1980 to 
2012. The empirical evidence showed that a trading threshold occurs below which greater trade openness is beneficial and affects economic growth. The evidence also shows that the Laffer Curve of trade (inverted U-curve) indicates non-fragility of linkage between economic growth and trade openness in SSA nations thus upholding the claim of a non-linearity relationship between trade openness and economic growth in SSA.

Using trade intensity index and a spatial interaction model specified as a Tobit regression, Hanink and Owusu (1998) investigated the direction of trade within the ECOWAS region. Empirical findings established that the intensity of the trade index remained the same before and after the formation of ECOWAS; leading to the conclusion that ECOWAS has been very inefficient in intraregional trade promotion within its territory.

Examining the effect of electricity consumption on economic growth in Beijing, Liu (2018) found that at an aggregated level, there is a unidirectional causality running from economic growth to electricity consumption at a one percent significant level. At the sectoral level, the primary sector reveals that electricity consumption impacts added value with two quarter lagged while the secondary and tertiary sectors reveal a unidirectional causality running from economic growth to electricity consumption. However, when the sectors were crossed, the economic growth of the secondary sector was found to have no impact on the tertiary sector while the economic growth of the tertiary sector significantly affects the secondary sector.

Damette (2018) did research and found that income and prices are the principal determinants of household energy consumption. The outcome of the multinomial logit model's estimate of marginal effects makes it clear that income has a germane effect on the energy choice of oil, gas, wood and electricity. The result clearly shows that the low-income level increases the probability of selecting wood while the high-income level influences the choice for electricity and gas.

\section{THEORETICAL FRAMEWORK AND METHODOLOGY}

\section{Theoretical framework}

This study explores a theoretical link between the Hecksher-Ohlin $(\mathrm{H}-\mathrm{O})$ model and Environmental Kuznets Curve (EKC) to analyze trade openness, energy consumption and development. The H-O theory of trade postulates that where there are perfect competition and no barriers to international trade, a country tends to specialize in the production of goods that uses its abundant resources intensively for export (Markusen et al, 1995; and Michieka et al, 2013). The application of this theory is more pronounced in the case of resource-rich developing countries that usually depend almost entirely on their natural resource endowment production and export. Intensive production and rising consumption of developing country's mineral products, as well as export of the same, is important for the economic growth of these economies. However, while mining activities and mineral export result in increased economic growth, such growth has implications for environmental quality.

Theoretically, the EKC hypothesis was developed by Kuznets (1955) to explain the relationship between environmental quality and economic growth. According to this hypothesis, at the initial stage of economic growth, carbon emission tends to increase continuously with rising income until a certain higher level of income is reached, after which an increase in income 
leads to a decline in carbon emission. Further development of the hypothesis by Grossman and Kruger (1995) led to three major effects of environment-economic activity linkage. One is the scale effect which shows that an increase in economic activities that raises the level of income will magnify carbon emission and deplete the economy's available resources. Two is the composition effect which refers to changes in production structure such as the gradual shift away from primary production (such as mining and agriculture) to heavy and resourceintensive industrial activities that leads to a high level of pollution. Three is the technique effect which crops up from the improvements in techniques of production and adoption of cleaner technologies that reduces pollution.

Furthermore, environmental quality has also been associated with the level of energy consumption, trade openness and urbanization. As an economy grows, there is a tendency for energy consumption to increase which could increase carbon emission, especially if such energy is dominated by fossil fuel (Reinhardt and von Falkenstein, 2011). In the same vein, international trade activities encourage imports of carbon-emitting items such as vehicles and other equipment. Also, a higher degree of urbanization is linked with higher levels of energy consumption with its attendant carbon emission.

\section{Model Specification}

The energy-trade-development theory seeks to establish the link between free trade, energy consumption and the development of an economy. The study specifies a modified version of the theoretical hypothesis as shown in equation (1):

GDPCAP $_{t}=\mathrm{F}(\mathrm{TRA}, \mathrm{FOS}, \mathrm{REN}, \mathrm{CO} 2, \mathrm{FID})$

Where GDPCAP is GDP per capita, TRA is trade openness, FOS is fossil fuel consumption, REN is renewable energy consumption, $\mathrm{CO} 2$ is $\mathrm{CO} 2$ emissions and FID is financial development.

The function is transformed into its natural logs to avoid a spurious analysis. In this regard, the semi log-linear form of the model is as shown in equation (2):

$\operatorname{GDPCAP}_{\mathrm{t}}=\beta_{0}+\beta_{1} \mathrm{TRA}_{\text {it }}+\beta_{2} \mathrm{FOS}_{\text {it }}+\beta_{3} \mathrm{REN}_{\text {it }}+\beta_{4} \mathrm{CO} 2_{\text {it }}+\beta_{5} \mathrm{FID}_{\text {it }}+\mathrm{U}_{\text {it }}$

Where, $\beta_{1}, \beta_{2}, \beta_{3}, \beta_{4}$, and $\beta_{5}$ are the coefficients to be estimated.

\section{Estimation Technique}

This study adopts the Panel Autoregressive Distributed Lag (ARDL) technique to empirically analyze the above functional forms. According to Pearson (2001), the methodology helps to establish the relationship among the variables after determining the lag order of the model. Also, it takes stationary regressors between 1 and 0 , while the long and short-run characteristics of the model can be addressed at the same time. As a next step, the study used constructed panel causality test proposed by Dumitrescu and Hurlin (2012) to dissect the endogenous interconnectedness among the covariates thereby validating the causal direction among the variables.

The ARDL representations of the above equations are as specified in equation (3): 
African Journal of Economics and Sustainable Development

ISSN: 2689-5080

Volume 4, Issue 1, 2021 (pp. 45-62)

www.abjournals.org

$\triangle G D P C A P=\beta_{0}+\beta i \Delta C O 2 E M I S S I O N C_{t-1}+\beta i \Delta$ TRA $_{\mathrm{t}-\mathrm{i}}+\beta i \Delta \mathrm{REN}_{\mathrm{t}-\mathrm{I}}+\beta i \Delta \mathrm{FOS}_{\mathrm{t}-\mathrm{I}}+$ $\beta i \Delta \mathrm{CO}_{\mathrm{t}-\mathrm{I}}+\beta i \Delta \mathrm{FID}_{\mathrm{t}-\mathrm{I}}+\beta i \Delta \mathrm{RENEWCONC}_{\mathrm{t}-\mathrm{I}}+\beta i \Delta$ GDPCAPITAC $_{\mathrm{t}-\mathrm{I}}+$ $\sum_{k=1}^{n} \quad \beta i \Delta \mathrm{GDPCAPC}_{\mathrm{t}-\mathrm{i}}+\sum_{k=1}^{n} \quad \beta i \Delta \mathrm{TRA}_{\mathrm{t}-\mathrm{i}}+\sum_{k=1}^{n} \quad \beta i \Delta \mathrm{REN}_{\mathrm{t}-\mathrm{I}}+\sum_{k=1}^{n} \quad \beta i \Delta \mathrm{FOS}_{\mathrm{t}-\mathrm{I}}+$ $\sum_{k=1}^{n} \quad \beta i \Delta \mathrm{CO} 2_{\mathrm{t}-\mathrm{I}}+\mathbf{U}_{\mathbf{i t}}$

The error correction model is as expressed in equation (4):

$\triangle G D P C A P=\beta_{0}+\sum_{k=1}^{n} \quad \beta i \Delta \mathrm{GDPCAPC}_{\mathrm{t}-\mathrm{i}}+\sum_{k=1}^{n} \quad \beta i \Delta \mathrm{TRA}_{\mathrm{t}-\mathrm{i}}+\sum_{k=1}^{n} \quad \beta i \Delta \mathrm{REN}_{\mathrm{t}-\mathrm{I}}+$ $\sum_{k=1}^{n} \quad \beta i \Delta \mathrm{FOS}_{\mathrm{t}-\mathrm{I}}+\sum_{k=1}^{n} \quad \beta i \Delta \mathrm{CO} 2_{\mathrm{t}-\mathrm{I}}+\sum_{k=1}^{n} \quad \beta i \Delta \mathrm{FID}_{\mathrm{t}-\mathrm{I}}+\sum_{k=1}^{n} \quad \beta i \Delta \mathrm{RENEWCONC}_{\mathrm{t}-\mathrm{I}}+$ $\sum_{k=1}^{n} \quad \beta i \Delta$ GDPCAPITAC $_{\mathrm{t}-\mathrm{i}}+\Theta_{\mathrm{i}} \mathrm{ECM}_{\mathrm{t}-1}+\mathbf{U}_{\mathrm{it}}$

The causality is examined by F-test using a null hypothesis

$\mathrm{Y}_{\mathrm{t}}=\alpha+\sum_{k=1}^{n} \quad \gamma_{\mathrm{k}} \mathrm{y}_{\mathrm{t}-\mathrm{k}}+\sum_{k=1}^{k} \quad \beta_{\mathrm{k}} \mathrm{X}_{\mathrm{t}-\mathrm{k}}+\varepsilon_{\mathrm{t}} \quad$ with $\mathrm{t}=1$, ,$T$

The basic idea is that, if the past values of $\mathrm{x}$ are significant predictors of the current value of $\mathrm{y}$ even when past values of $\mathrm{y}$ have been included in the model, then $\mathrm{x}$ exerts a causal influence on $y$. The causality is investigated based on an F-test with the following null hypothesis:

$\mathrm{H}_{0}: \beta_{1}=\ldots \ldots . .=\beta_{\mathrm{k}}=0$

If $\mathrm{H}_{0}$ is rejected, one can conclude that causality from $\mathrm{x}$ to $\mathrm{y}$ exists. The $\mathrm{x}$ and $\mathrm{y}$ variables are interchanged to test for causality in the other direction, and it is possible to observe bidirectional causality.

\section{Data Requirement and Sources}

The panel data set for this study covers between 1971 and 2017 for the seven major oilproducing countries in Africa: Nigeria, Algeria, Congo, Egypt, Gabon, Sudan and Tunisia. Table 4 presents the variables for this study which will be transformed into natural logarithms. All the data are sourced from the World Bank World Development Indicators (WDI).

Table 4. Data Requirement and Sources

\begin{tabular}{|c|c|c|c|c|c|}
\hline $\mathbf{S} / \mathbf{N}$ & Variables & Description & Unit of Measurement & Source & $\begin{array}{c}\text { Theoretical } \\
\text { Expectations }\end{array}$ \\
\hline 1. & GDPCAP & GDP per capita & constant 2010 US\$ & WDI & \\
\hline 2 & TRA & Trade Openness & Trade (\% of GDP) & WDI & Positive (+) \\
\hline 3 & FOS & $\begin{array}{l}\text { Fossil Fuel } \\
\text { Consumption }\end{array}$ & (\% of total) & WDI & Positive (+) \\
\hline 4 & REN & $\begin{array}{l}\text { Renewable } \\
\text { energy } \\
\text { consumption }\end{array}$ & $\begin{array}{l}\text { Combustible } \\
\text { renewables } \\
\text { and waste (\% of total } \\
\text { energy) }\end{array}$ & WDI & Positive (+) \\
\hline 5 & $\mathrm{CO} 2$ & $\mathrm{CO} 2$ emissions & (kt) & WDI & Negative (-) \\
\hline 6 & FID & $\begin{array}{l}\text { Financial } \\
\text { Development }\end{array}$ & $\begin{array}{l}\text { Domestic credit to the } \\
\text { private sector ( } \% \text { of GDP) }\end{array}$ & WDI & Positive (+) \\
\hline
\end{tabular}

Source: Author's Compilation 
African Journal of Economics and Sustainable Development

ISSN: 2689-5080

Volume 4, Issue 1, 2021 (pp. 45-62)

www.abjournals.org

\section{EMPIRICAL RESULT ANALYSIS}

\section{Panel Unit Root Test}

To test for unit root, this study used the Levin-Lin-Chiu, Im-Pesaran-shin and Breitung tests. This helped to ascertain whether the variables are stationary at levels or first difference. These tests are used to control for spurious or nonsense regression. The unit root test results in Table 5 shows that real GDP per capita, renewable energy consumption and financial development are stationary at first difference while trade openness, $\mathrm{CO} 2$ emission and fossil fuel consumption are stationary at levels. By implication, the stationarity of variables is in mixed order $\mathrm{I}(0)$ and $\mathrm{I}(1)$.

Table 5: Panel Unit Root Test

\begin{tabular}{|c|c|c|c|c|c|c|c|}
\hline \multirow{2}{*}{ Variables } & \multicolumn{2}{|c|}{ Im-Pesaran-Shin } & \multicolumn{2}{|c|}{ Levin-Lin-Chu } & \multicolumn{2}{|c|}{ Breitung } & \multirow[t]{2}{*}{$\begin{array}{c}\text { Order of } \\
\text { integration }\end{array}$} \\
\hline & Level & $\begin{array}{c}\text { First } \\
\text { Difference }\end{array}$ & Level & $\begin{array}{c}\text { First } \\
\text { Difference }\end{array}$ & Level & $\begin{array}{c}\text { First } \\
\text { Difference }\end{array}$ & \\
\hline LNGDPCAP & 0.3516 & $-6.2021 * * *$ & $-1.6181^{*}$ & $-3.5728 * * *$ & 2.7711 & $-5.4277 * * *$ & $\mathrm{I}(1)$ \\
\hline LNTRA & $-3.1875 * * *$ & $-9.7662 * * *$ & $-3.466 * * *$ & $-8.1358 * * *$ & -1.1292 & $-4.8335 * * *$ & $\mathrm{I}(0)$ \\
\hline LNREN & 0.2010 & $-10.8011 * * *$ & $-2.2168 * *$ & $-9.344 * * *$ & 2.2855 & $-3.3103 * * *$ & $\mathrm{I}(1)$ \\
\hline LNFOS & $-2.4082 * * *$ & $-9.5231 * * *$ & $-3.7764 * * *$ & $-7.8825 * * *$ & 1.9864 & $-2.8595 * * *$ & $\mathrm{I}(0)$ \\
\hline LNFID & -0.8178 & $-8.2184 * * *$ & -1.2061 & $-7.0186 * * *$ & -0.8481 & $-7.1051 * * *$ & $\mathrm{I}(1)$ \\
\hline $\mathrm{LNCO} 2$ & $-2.1365 * *$ & $-11.709 * * *$ & $-4.1154 * * *$ & $-11.2417 * * *$ & 3.3828 & $-2.4006 * * *$ & $\mathrm{I}(0)$ \\
\hline
\end{tabular}

Source: Author's Computation $\quad * * * p<0.01, * * p<0.05, * p<0.1$

\section{Hausman test}

The null hypothesis expresses that the preferred model is random effects. The alternate hypothesis is that the model is fixed effects. Essentially, the tests look to see if there is a correlation between the unique errors and the regressors in the model. The null hypothesis is that there is no correlation between the two. The Hausman test hence shows that the mean group heterogeneous Autoregressive Distribution Lag is the best estimation technique for the study.

Table 6: Hausman Unit Root Test

\begin{tabular}{|c|c|c|c|c|}
\hline \multicolumn{5}{|c|}{ Hausman mg pmg, sigmamore } \\
\hline Variable & MG & PMG & Difference & S.E. \\
\hline TRA & -4.909 & 7.479 & -12.389 & 43.786 \\
\hline REN & 155.53 & -3.891 & 159.421 & 177.2 \\
\hline FOS & -16.228 & 127.273 & -143.501 & 311.47 \\
\hline FID & -109.82 & -69.179 & -40.641 & 125.926 \\
\hline CO2 & -0.375 & -0.046 & -0.329 & 0.491 \\
\hline
\end{tabular}

Source: Author's Computation 
African Journal of Economics and Sustainable Development

ISSN: $2689-5080$

Volume 4, Issue 1, 2021 (pp. 45-62)

www.abjournals.org

$$
\begin{aligned}
& \mathrm{b}=\text { consistent under Ho and Ha; obtained from xtpmg } \\
& \mathrm{B}=\text { inconsistent under Ha, efficient under Ho; obtained from xtpmg }
\end{aligned}
$$

Test: Ho: difference in coefficients not systematic

$$
\operatorname{chi} 2(5)=19.25(0.0017)
$$

\section{Panel ARDL Estimation}

The empirical result from the ARDL estimation in Table 7 shows that trade openness is a significant factor that determines the economic development of oil-producing countries in Africa, both in the short and long run. A percentage increase in trade openness decreases economic development by about 7.0 percent but in the long run, boasts development by 28.0 percent. The economic implication of this is that while trade openness can pose some challenges in the short run if not well managed, it is however an economic driver for oilproducing African countries in the long run as also evident in the study of Pradhan (2017). Accessing specific countries, trade openness also has a positive relationship with economic development in Nigeria and Sudan in the short run and translates to the long run which now includes other countries except for Tunisia which could be due to the unitary semi-presidential republic being practised.

A percentage increase in renewable energy consumption induces about a 16.0 percent increase in real GDP per capita of selected countries in Africa as against the 12.0 percentage decrease in the short run. By implication, it can be said that renewable energy consumption can save the future of the continent as also evident in the study of Eberhard et al. (2011). A percentage point increase in renewable energy consumption for Nigeria, Congo, and Gabon will result in about 16.6, 86.7 and 59.8 percent increase in economic development respectively. Amidst other countries, renewable energy consumption tends to affect Egypt economic development significantly in the long run by a decrease of about 12.0 percentage for every percentage increase in renewable energy consumption due to its poor global ease of doing business ranking as compared to other oil-producing countries in Africa.

A percentage increase in fossil fuel consumption induces a 78.0 percent decrease in the short run real GDP per capita of selected countries in Africa. The result further revealed that fossil fuel significantly influences Algeria and Tunisia development in the short run while countries like Nigeria, Algeria, Egypt and Gabon are significantly impacted in the long run. Also, fossil fuel consumption is seen to have a negative effect on development both in the short and long run for Nigeria and Sudan due to the increasing consumption and dependence on oil in these countries for transportation and electricity generation.

Financial development through domestic credit to the private sector has not been seen to have a tangible impact on development majorly as a result of the increasing cost of credit in the continent. From the result, a negative relationship exists between financial development and development both in the short and long run. A percentage point increase in domestic credit to the private sector induces a two-percentage decrease in development in the short run and increased to 46.0 percent in the long run. However, countries like Nigeria and Algeria benefit 
African Journal of Economics and Sustainable Development

ISSN: $2689-5080$

Volume 4, Issue 1, 2021 (pp. 45-62)

www.abjournals.org

positively from financial development in the short run and sustained by Nigeria in the long run with Egypt joining.

Externality through carbon emission, emitted negatively, jointly affect the economic development of oil-producing countries in Africa in the short run and becomes positively significant in the long run. A possible reason for this is the lower emission of carbon by African countries as compared to major emitters like China and the United States. Specifically, Egypt and Sudan experienced a negative impact in the short run while Algeria and Congo experienced a negative impact on development in the long run. A one percent change in $\mathrm{CO} 2$ emission will induce about 11.9 and 19.3 percentage change in real GDP per capita for Egypt and Sudan respectively. Also, a percentage increase in $\mathrm{CO} 2$ emission will induce about a 0.71 decrease in real GDP per capita for Algeria.

Table 7: Panel ARDL Estimation

\begin{tabular}{|c|c|c|c|c|c|c|c|c|}
\hline Variables & Panel & Nigeria & \begin{tabular}{|l|} 
Algeria \\
\end{tabular} & Egypt & Congo & Gabon & Sudan & Tunisia \\
\hline \multirow[t]{2}{*}{ ECT } & $-0.193 * * *$ & $-0.145 * * *$ & -0.168 & $-0.507 * * *$ & $-0.0691 *$ & $-0.278 * *$ & $-0.127 * *$ & -0.0567 \\
\hline & -0.0592 & -0.0558 & -0.124 & -0.0876 & -0.0418 & -0.125 & -0.0556 & -0.0524 \\
\hline \multirow[t]{2}{*}{ D.Intra } & $-0.0700 *$ & 0.0249 & -0.047 & $-0.0399 * * *$ & -0.0367 & $-0.291^{*}$ & 0.00195 & $-0.102 *$ \\
\hline & -0.0398 & -0.0246 & -0.0581 & -0.0155 & -0.0596 & -0.165 & -0.042 & -0.0565 \\
\hline \multirow[t]{2}{*}{ D.Inren } & -0.124 & -1.134 & -0.0093 & 0.0154 & -0.0755 & 0.23 & 0.0584 & 0.0471 \\
\hline & -0.172 & -1.212 & -0.0124 & -0.0505 & -0.119 & -0.313 & -0.0783 & -0.0791 \\
\hline \multirow[t]{2}{*}{ D.Infos } & $\begin{array}{l}-0.779 \\
\end{array}$ & -0.319 & $-7.364 *$ & 0.0736 & -0.0207 & -0.0856 & 0.03 & $2.233 * * *$ \\
\hline & -1.145 & -0.256 & -4.304 & -0.393 & -0.0892 & -0.206 & -0.0854 & -0.834 \\
\hline \multirow[t]{2}{*}{ D.Infid } & -0.0176 & 0.000202 & $0.0286^{*}$ & -0.0134 & -0.0114 & -0.0582 & -0.00781 & -0.0612 \\
\hline & -0.0121 & -0.0336 & -0.0163 & -0.0168 & -0.0339 & -0.0716 & -0.0464 & -0.0556 \\
\hline \multirow[t]{3}{*}{ D.Inco2 } & -0.0219 & 0.00824 & 0.0314 & $-0.119 * * *$ & $0.0687 * * *$ & 0.0678 & $-0.193 * *$ & -0.0174 \\
\hline & -0.0374 & -0.0445 & -0.0395 & -0.0463 & -0.0247 & -0.125 & -0.0753 & -0.0819 \\
\hline & & \multicolumn{5}{|c|}{ Long Run Result } & & \\
\hline \multirow[t]{2}{*}{ Intra } & $0.284 *$ & $0.349 * *$ & $0.531 * *$ & $0.0426 *$ & 0.906 & 0.337 & 0.125 & -0.305 \\
\hline & -0.145 & -0.171 & -0.251 & -0.0251 & -0.572 & -0.56 & -0.252 & -0.821 \\
\hline \multirow[t]{2}{*}{ Inren } & 0.166 & 0.213 & -0.0596 & $-0.116^{* *}$ & 0.867 & 0.598 & -0.0443 & -0.296 \\
\hline & -0.159 & -0.513 & -0.0647 & -0.0571 & -0.55 & -0.427 & -0.248 & -1.255 \\
\hline \multirow[t]{2}{*}{ Infos } & $0.622 *$ & $-0.796 * *$ & $1.335^{* *} *$ & $0.453 * * *$ & 0.952 & $0.749 *$ & -0.412 & 2.073 \\
\hline & -0.373 & -0.336 & -0.623 & -0.123 & -0.612 & -0.387 & -0.658 & -3.365 \\
\hline \multirow[t]{2}{*}{ Infid } & -0.462 & 0.112 & -0.0177 & 0.00261 & -0.103 & -0.394 & -0.131 & -2.705 \\
\hline & -0.379 & -0.207 & -0.0939 & -0.0167 & -0.212 & -0.243 & -0.139 & -2.745 \\
\hline \multirow[t]{2}{*}{ Inco2 } & $0.482 * *$ & $0.671 * * *$ & -0.0071 & $0.466 * * *$ & -0.405 & $0.433^{*}$ & $0.953 * * *$ & $1.260 * *$ \\
\hline & -0.212 & -0.238 & -0.291 & -0.0397 & -0.475 & -0.261 & -0.279 & -0.562 \\
\hline \multirow[t]{2}{*}{$\mathbf{C}$} & $5.305^{*}$ & 0.912 & 20.11 & 2.311 & 0.0223 & $\begin{array}{c}10.24 * * \\
*\end{array}$ & 0.0906 & 3.448 \\
\hline & -2.805 & -1.882 & -14.09 & -1.983 & -0.732 & -2.212 & -0.714 & -2.163 \\
\hline Obs & 322 & 322 & 322 & 322 & 322 & 322 & 322 & 322 \\
\hline
\end{tabular}


African Journal of Economics and Sustainable Development

ISSN: $2689-5080$

Volume 4, Issue 1, 2021 (pp. 45-62)

www.abjournals.org

\section{Granger Causality Tests}

The Dumitresca and Hulin (2012) Granger causality test shows that causality exists between trade openness and economic development in the oil-producing country in Africa. This means that trade openness induces economic development and in reverse, economic development induces trade openness as evident in the probability value of less than one percent allowing for the rejection of the null hypothesis.

Also, renewable energy consumption is seen to cause economic development while in return, development does not necessarily induce increased consumption of renewable energy. Therefore, causality does not exist between renewable consumption and real GDP per capita. Finally, causality exists between fossil fuel consumption and economic development as evident from the probability value of the causality test. This implies that fossil fuel consumption affects the economic development of oil-producing countries in Africa and in reverse, economic development also induces fossil fuel consumption.

Table 8: Dumitrescu \& Hurlin -Granger causality test

\begin{tabular}{|l|c|c|}
\hline \multicolumn{3}{|c|}{ Dumitrescu \& Hurlin -Granger causality test } \\
\hline H0: Intra does not Granger-cause lngdpcap. & Co-efficient & p-value \\
\hline Z-bar & 3.742 & 0.000 \\
\hline Z-bar tilde & 3.247 & 0.001 \\
\hline H0: lngdpcap does not Granger-cause lntra. & & \\
\hline Z-bar & 2.805 & 0.005 \\
\hline Z-bar tilde & 2.403 & 0.016 \\
\hline H0: lnren does not Granger-cause lngdpcap. & & 0.000 \\
\hline Z-bar & 5.673 & 0.000 \\
\hline Z-bar tilde & 4.987 & 0.210 \\
\hline H0: lngdpcap does not Granger-cause lnren. & & 0.315 \\
\hline Z-bar & 1.254 & \\
\hline Z-bar tilde & 1.004 & 0.000 \\
\hline H0: lnfos does not Granger-cause lngdpcap. & & 0.000 \\
\hline Z-bar & 4.604 & 0.000 \\
\hline Z-bar tilde & 4.024 & 0.000 \\
\hline H0: lngdpcap does not Granger-cause lnfos. & & \\
\hline Z-bar & 6.549 & 5.776 \\
\hline Z-bar tilde & & \\
\hline
\end{tabular}

Source: Author's Computation 


\section{SUMMARY, CONCLUSION AND RECOMMENDATIONS}

\section{Summary and Conclusion}

This research was conducted to investigate energy consumption, trade openness and economic development in some selected oil-producing countries in Africa. The Levin-Lin-Chiu, PesaranShin and Breitung test was used to ascertain the stationarity of the variables in the model. It reveals that GDP per capita, renewable energy consumption and financial development are stationary at first difference while trade openness, fossil consumption and $\mathrm{Co} 2$ emission are stationary at level. The Hausman test shows that the mean group heterogeneous ARDL is the best estimation technique for the study to estimate the short and long-run relationship of the model using secondary data sourced from WDI from 1971 to 2017.

The study found trade openness as a significant factor determining the economic development of oil-producing countries in Africa both in the short and long run. A percentage increase in trade openness in the short run decreases economic development significantly while it also boosts development in the long run. This implies that while trade openness can pose some challenges in the short run, if not well managed, it is an economic driver for the oil-producing African countries in the long run. Accessing specific countries, trade openness has a positive relationship with economic development in Nigeria and Sudan in the short run and translates into the long run even for the other countries except for Tunisia possibly because of the unitary semi-presidential system of government being practised.

A percentage increase in renewable energy consumption induces a significant percentage increase in real GDP per capita of selected countries in Africa implying that renewable energy consumption can save the future of the continent as also confirmed by the study of Eberhard, et al. (2011). Also, the study found a positive relationship between renewable energy and development for Nigeria, Congo and Gabon in the long run while the other countries showed a negative relationship. Amidst other countries, renewable energy consumption tends to affect Egypt's economic development significantly in the long run perhaps due to its poor global ease of doing business ranking as compared to other oil-producing countries in Africa. The study also found that a percentage increase in fossil fuel consumption induces a very significant decrease in real GDP per capita in the short run for the selected countries. However, fossil fuel showed a significant influence on development in Algeria and Tunisia in the short run but impacted Nigeria, Algeria, Egypt and Gabon significantly in the long run. Furthermore, fossil fuel consumption is seen to have a negative effect on development both in the short and long run for Nigeria and Sudan because of the increasing consumption and dependence on oil for transportation and electricity generation in these countries.

The Granger causality test showed that causality exists between trade openness and economic development in the selected oil-producing countries. That is, trade openness induces economic development and in reverse economic development induces trade openness as evident in the probability value of less than one percent thus allowing for the rejection of the null hypothesis. Also, renewable energy consumption is seen to cause economic development but in return, development does not necessarily induce increased consumption of renewable energy. Therefore, a bidirectional causality does not exist between renewable energy and real GDP per capita. Finally, causality exists between fossil fuel consumption and economic development as evident from the probability value of the causality test. This implies that fossil fuel consumption affects the economic development of oil-producing countries in Africa and in 
reverse, economic development also induces fossil fuel consumption. Based on these findings, it can be concluded that trade openness and the nature of energy consumed have a significant impact on economic development in the selected oil-producing countries in Africa.

\section{Policy Recommendation}

Based on the above findings, it is therefore recommended that policies should be channelled to favour enabling environment, African free trade zone, economic freedom, private financial growth, ease of doing business, energy efficiency, renewable energy, carbon capture and storage, private property rights and security. The following are specifically recommended:

1. Need to implement national, provincial and local enabling policies and regulations such as improved financial development, reduced tax burden and liberalization of trade in Africa that will voluntarily encourage diversification of energy mix to include all the renewable energy options such as wind, biomass, wind, solar, micro-hydro, and nuclear technologies.

2. Apart from the signed consent by most African counties on the African free trade zone treaty as a tendency to remove tariffs, trade barriers, as well as the successful commercialization of trade, compliance with investments, properties and policies, African institutions, should put to action the cooperation in all business-related issues, custom matters and the execution of trade measures, providing a channel for the resolution of crisis concerning responsibilities as well as maintaining an organizational framework on which the execution of AfCFTA is promoted.

3. Conscious efforts should be made to improve the ease of doing business and economic freedom index in Africa. Factors such as rule of law, reduced regulation of starting a business, financial freedom, minimum legislation, upholding of ease trade, low taxation, less corruption among others are instrumental in its achievement.

4. There should be a reduction of tariff in order to facilitate trade and free flow of investment from an external source and thus facilitate growth. Africa is blessed with abundant natural and human resources that need to be harnessed efficiently.

\section{REFERENCES}

Ackah, I., Adu, F. and Opoku, R. T., (2014). On the Demand Dynamics of Electricity in Ghana: Do Exogenous Non-Economic Variables Count. International Journal of Energy Economics and Policy, vol. 4, no. 2, 149-153.

African Development Bank (AfDB), 2017, Annual Development Effectiveness Review 2017: Chapter 2-Light Up and Power Africa, AfDB, Abidjan.

Damette, O. and Seghir, M. (2018). Natural resource curse in oil-exporting countries: A nonlinear approach. International Economics, No. $156 \cdot \mathrm{Q} 4$.

Dumitresscu, E. I. and Hurlin, C. (2012). Testing for Granger non-causality in heterogenous panels. Economic Modelling, vol. 29, issue 4, 1450-146. 
Eberhard, A., Rosnes, O., Shkaratan, M. and Vennemo, H. (2011). Africa's Power Infrastructure: Investment, Integration, Efficiency. Washington, DC: The World Bank Group, Report No. 61309, vol.1.

Grossman, G.M., and Krueger, A.B., (1995). Economic growth and the environment. Quarterly Journal of Economics. Vol. 110, issue 2, 353-377.

Hanink, M. Dean and Owusu, Henri (1998). "Has ECOWAS Promoted Trade Among Its Members?" Journal of African Economies, Vol. 7, No. 3, 363-383.

IEA (International Energy Agency), 2017a, Energy Access Outlook: World Energy Outlook Special Report, OECD/IEA, Paris

Jung W. S. and Marshall, P. J. (1985). Exports, growth and causality in developing countries. Journal of Development Economics, 1985, vol. 18, issue 1, 1-12

Kuznets, S. (1955). Economic Growth and Income Inequality. American Economic Review Vol. 45, No. 1, 1-28

Lise, W. and van Montort, K. (2014). Energy consumption and GDP in Turkey: is there a co integration relationship? Energy Economics, vol.29, issue 6, 1166-1178

Liu, D., Ruan, L., Liu, J., Huan, H., Zhang, G., Feng, Y. and Li, Y. (2018). "Electricity consumption and economic growth nexus in Beijing: A causal analysis of quarterly sectoral data," Renewable and Sustainable Energy Reviews, Elsevier, vol. 82(P3), 24982503

Markusen, J., Melvin, J., Maskus, K. and Kaempfer, W. (1995). International Trade: Theory and Evidence. University Library of Munich, Germany, MPRA Paper.

Michieka, N. M., Fletcher, J. and Burnett, W., (2013). "An empirical analysis of the role of China's exports on CO2 emissions," Applied Energy, vol.104, 258-267

Pearson, P J G and Fouquet, R (2003). Long Run Carbon Dioxide Emissions and Environmental Kuznets Curves: different pathways to development, Ch. 10 in Hunt, L C (ed.) Energy in a Competitive Market, Edward Elgar, Cheltenham.

Pradhan, P, Costa, L., Rybski, D., Lucht, W. and Kropp, J. (2017). A Systematic Study of Sustainable Development Goal (SDG) Interactions. Earth's Future, Vol 5, issue 11.

Reinhardt, G.A. and vonFalkenstein, E. (2011). Environmental assessment of biofuels for transport and the aspects of land use Competition. Biomass and Bioenergy, vol.35 no.6, $2315-2322$

Zahonogo, P (2017). Trade and economic growth in developing countries: Evidence from sub-Saharan Africa. Journal of African Trade. Vol.3, issue 1-2, 41-56.

Zeren, F and Ari, A. (2013). Trade Openness and Economic Growth: A Panel Causality Test. International Journal of Business and Social Science, vol. 4 no 9, 317-324. 